\title{
Current topics in interventional cardiology
}

\author{
Ion S. Jovin \\ Hunter Holmes McGuire VA Medical Center and Virginia Commonwealth University, Richmond, VA, USA \\ Correspondence to: Ion S. Jovin, MD, ScD. Hunter Holmes McGuire VA Medical Center and Virginia Commonwealth University, 1201 Broad Rock \\ Blvd 111J, Richmond, VA 23249, USA. Email: isjovin@yahoo.com.
}

Submitted Jan 30, 2020. Accepted for publication Feb 23, 2020.

doi: $10.21037 /$ jtd.2020.02.09

View this article at: http://dx.doi.org/10.21037/jtd.2020.02.09

Interventional cardiology is evolving rapidly and the development of new technologies along with our evolving understanding of best treatment methods has changed the landscape of interventional cardiology significantly. This supplement to the Fournal of Thoracic Disease tries to provide a contemporary perspective over different topics of interest for interventional cardiologists but also for interventional cardiology trainees, general cardiologists and internists with an interest in cardiology.

Most people would agree that the development of transcatheter valve therapy has been a significant moment in the evolution of interventional cardiology. In this issue, Dr. Vasa-Nicotera and colleagues gives an overview (1) over new developments in transcatheter aortic valve repair (TAVR), while Dr. Claudia Walther and colleagues provides a review of current mitral valve therapies (2). Both reviews allow a glance into the future and show us how the field is continuing to develop. Peripheral vascular disease and its percutaneous treatment has also seen significant growth and Drs. Kokkinidis and Armstrong present a comprehensive overview of developments in endovascular therapy of peripheral arterial disease (3) which is especially interesting in the light of the paclitaxel-coated devices controversy which is still ongoing.

Other topics are related to coronary interventions: Dr. Antonazzo and colleagues present an umbrella review of oral antiplatelet therapy in elderly patients undergoing percutaneous interventions (4), Dr. Hizoh and colleagues present an overview of risk scores predicting outcomes in patient undergoing primary percutaneous interventions (5), while Dr. Patel and colleagues discuss ways of optimizing the outcomes of percutaneous coronary interventions in patients with stable angina (6).

Other topics are topics of general interest for all cardiologists working in the cath lab, whether performing coronary interventions, or peripheral interventions or structural interventions: Drs. Riso and Vidovich review methods of minimizing radiation in the cardiac catheterization laboratory (7). Dr. Hauq and colleagues provide a review of the topic of contrast-induced acute kidney injury or contrast-induced nephropathy (8) and last but certainly not least, Dr. Henien and colleagues reviews the very important topic of quality assurance and quality management in the cardiac catheterization laboratory (9).

I hope that you will enjoy reading the interventional cardiology-focused supplement of the Fournal of Thoracic Disease.

\section{Acknowledgments}

Funding: None.

\section{Footnote}

Provenance and Peer Review: This article was commissioned by the editorial office, Fournal of Thoracic Disease for the series "Interventional Cardiology". The article did not undergo external peer review.

Conflicts of Interest: The author has completed the ICMJE uniform disclosure form (available at http://dx.doi. org/10.21037/jtd.2020.02.09). The series "Interventional Cardiology" was commissioned by the editorial office without any funding or sponsorship. ISJ served as the unpaid Guest Editor of the series.

Ethical Statement: The author is accountable for all aspects of the work in ensuring that questions related 
to the accuracy or integrity of any part of the work are appropriately investigated and resolved.

Open Access Statement: This is an Open Access article distributed in accordance with the Creative Commons Attribution-NonCommercial-NoDerivs 4.0 International License (CC BY-NC-ND 4.0), which permits the noncommercial replication and distribution of the article with the strict proviso that no changes or edits are made and the original work is properly cited (including links to both the formal publication through the relevant DOI and the license). See: https://creativecommons.org/licenses/by-nc-nd/4.0/.

\section{References}

1. Vasa-Nicotera M, Mas-Peiro S, Fichtlscherer S, et al. Current issues in transcatheter aortic valve replacement. J Thoracic Dis 2020. doi: 10.21037/jtd.2020.01.10

2. Jovin IS. Current topics in interventional cardiology. J Thoracic Dis 2020. doi: 10.21037/jtd.2020.02.09

3. Kokkinidis DG, Armstrong EJ. Current developments in endovascular therapy of peripheral vascular disease. J Thoracic Dis 2019. doi: 10.21037/jtd.2019.12.130

Cite this article as: Jovin IS. Current topics in interventional cardiology. J Thorac Dis 2020;12(4):1646-1647. doi: 10.21037/ jtd.2020.02.09
4. Biondi-Zoccai G, Antonazzo B, Giordano A, et al. Oral antiplatelet therapy in the elderly undergoing percutaneous coronary intervention: an umbrella review. J Thoracic Dis 2019. doi: $10.21037 / j t d .2019 .12 .87$

5. Hizoh I, Domokos D, Banhegyi G, et al. Mortality prediction algorithms for patients undergoing primary percutaneous coronary intervention. J Thoracic Dis 2019. doi: $10.21037 /$ jtd.2019.12.83

6. Patel DB, Shah R, Jovin IS. Improving outcomes of percutaneous coronary interventions in patients with stable ischemic heart disease. J Thoracic Dis 2019. doi: 10.21037/jtd.2019.11.17

7. Biso SM, Vidovich MI. Radiation protection in the cardiac catheterization laboratory. J Thoracic Dis 2019. doi: 10.21037/jtd.2019.12.86

8. Haq MFU, Yip CS, Arora P. The conundrum of contrastinduced acute kidney injury. J Thoracic Dis 2019. doi: 10.21037/jtd.2019.12.88

9. Henien S, Aronow HD, Abbott JD. Quality management in the cardiac catheterization laboratory. J Thoracic Dis 2019. doi: $10.21037 /$ jtd.2019.12.81 